\title{
HYDROTHERMAL ZIRCON, NB-TA AND REE MINERALIZATION IN RADIOACTIVE PEGMATITE-APLITE DYKES, NORTH RAS MOHAMMED AREA, SOUTH SINAI, EGYPT
}

Mahmoud M. A. Gabr

Nuclear Materials Authority, Egypt P.O.Box. 530

(Received: 5- August 2007)

\begin{abstract}
The alkaline pegmatite-aplite dyke system hosted in alkaline granite was identified in the north Ras Mohammed area, south Sinai, Egypt. It consists of brown-red dykes up to several kilometers long and one meter wide. The system is generally trending NE-SW, E-W, N-S and NW-SE directions. The dykes are fine to medium-grained rocks with granular texture and are mainly composed of $\mathrm{K}$-feldspar as microperthite, quartz, riebeckite and plagioclase. The dykes have anomalous radioactivity up to $305 \mathrm{ppm}$ $U$. They are characterized by the presence of hydrothermal zircon (enriched with $U, T h$ and trace elements) which recorded for the first time in Sinai as far as the author is aware, in addition to Th (53 to $735.6 \mathrm{ppm}), \mathrm{Nb}(91.7$ to $5121.9 \mathrm{ppm}), \mathrm{Ta}(8.5$ to $693.5 \mathrm{ppm}), \mathrm{Y}$ (81.9 to $1915.8 \mathrm{ppm}), \mathrm{Zr}$ (623 to $16950.4 \mathrm{ppm})$, La (9.8 to 275.6

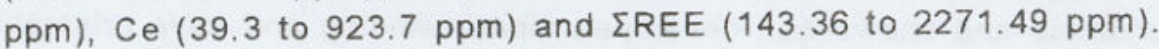
Based on scanning electron microscope (SEM) technique studies, some of the previously mentioned elements form its own minerals, such as hydrothermal zircon, columbite mineral group and Tornebohmite-(Ce) minerals.
\end{abstract}

\section{Introduction}

In general, alkaline granitoid rocks contain rare metal deposits ( $\mathrm{Zr}$-Hf-Nb-Ta-REE etc.) Clarke (1992). Jackson et al. (1985) and Kinnaird et al. (1985) mentioned that the mineralized plutons are late in the magmatic cycle, that high levels of fluorine may indicate that it was responsible for complexing the REEs and other high field-strength (HFS) elements, and that the mineralization occurs as disseminations both in the host pluton and in the matrices of breccia pipes, and as concentrated zones in aplite-pegmatite-dyke system. The influence of $F$ may go all the way back to the depleted source region at the time of partial melting. The alkaline granites and few pegmatites are of particular interest in the exploration for $\mathrm{Zr}, \mathrm{Nb}, \mathrm{Ta}, \mathrm{Be}, \mathrm{Y}$, and rare earth element (REE) mineral resources (e.g. Currie, 1976; Sinclair et al., 1992; Sörensen, 1992; Richardson and Birkett, 1995).

The present aplite-pegmatite dykes system is hosted by alkaline granites at Wadi Lathi, south Sinai, Egypt has high radiometric anomalies and rare earth elements REE mineralization (Moselhi 2006). These dykes also contained a hydrothermal zircon which incorporate considerable amount of uranium, thorium 
and REE. The term "hydrothermal zircon" is an imprecise term that may in a general way be used to refer to zircon crystallized from or altered by an aqueous fluid.

In this paper a geological map of the pegmatite-aplite dykes, exposed in north Ras Mohammed area involving petrography, major- and trace elements and REE geochemistry has been given. Hydrothermal zircon, U, Th and REEs-bearing minerals will be studied using SEM technique.

\section{Field description and petrography}

The aplite-pegmatite dykes are previously mentioned by Mosalhi, (2006) during his studies on the granitoid rocks of Ras Mohammed area, south Sinai (Fig.1). They occur as intersected dykes with different trends and sizes. These dykes are hosted by the alkaline granites without clear sharp contact. The diffusive nature of these contacts may suggest the late stage alkaline magma emplacement of these dykes. The dykes have different widths ranging from $40 \mathrm{~cm}$ to one meter (Fig. 2). They are medium to very coarse-grained with brownish red colour. They also subjected to severe alteration due to the effects of hydrothermal solutions manifested by both hematitization and kaolinitization, especially at the contact with the hosted rocks, in addition to the presence of hydrothermal zircon.

The aplite-pegmatite dykes are composed mainly of quartz, k-fldspar, riebeckite and minor plagioclase. Quartz occurs in subhedral grains filling the interspaces between the other constituents. It shows some cracking and undulose extinction due to deformation effects. Potash feldspars are mostly represented by fine string microperthite occasionally corroded by quartz. Plagioclase is less in abundance and shows well developed albite twinning and have prismatic nature and relatively fresh. Riebeckite occurs as subhedral crystals with blue colour. The presence of riebeckite suggests the alkaline affinities of these dykes (Fig. 3).

\section{Sampling and analytical Techniques}

The separation of heavy minerals was carried by using heavy liquids separation technique in the laboratories of the Nuclear Materials Authority of Egypt. Major oxides, trace elements and REE were analyzed in ACME Analytical Laboratories, LTD., Vancouver, Canada. Mineral chemistry was determined using SEM attached with EDAX unit, Nuclear Materials Authority, Egypt.

\section{Geochemistry}

Eight samples were collected from the aplite-pegmatite dykes for chemical analyses; five samples were chosen for major oxides analyses while all the eight samples were analyzed for trace and rare earth elements.

The data obtained of the major oxides and ClPW norms are given in Table 1.

Figure 4 represents the R1-R2 discrimination diagram of De La Roche et al. $(1980)$, where $R 1=(4 \mathrm{Si}-11(\mathrm{Na}+\mathrm{K}))-2(\mathrm{Fe}+\mathrm{Ti})$ and $\mathrm{R} 2=6 \mathrm{Ca}+2 \mathrm{Mg}+\mathrm{Al}$ (millications), the samples of aplite-pegmatite rocks fall within alkali granite field (Fig. 4). The presence of acmite in most samples suggests the alkaline nature of the studied aplite-pegmatite dykes. 
Mahmoud M. A. Gabr ; Hydrothermal Zircon, Nb-Ta and REE mineralization.......

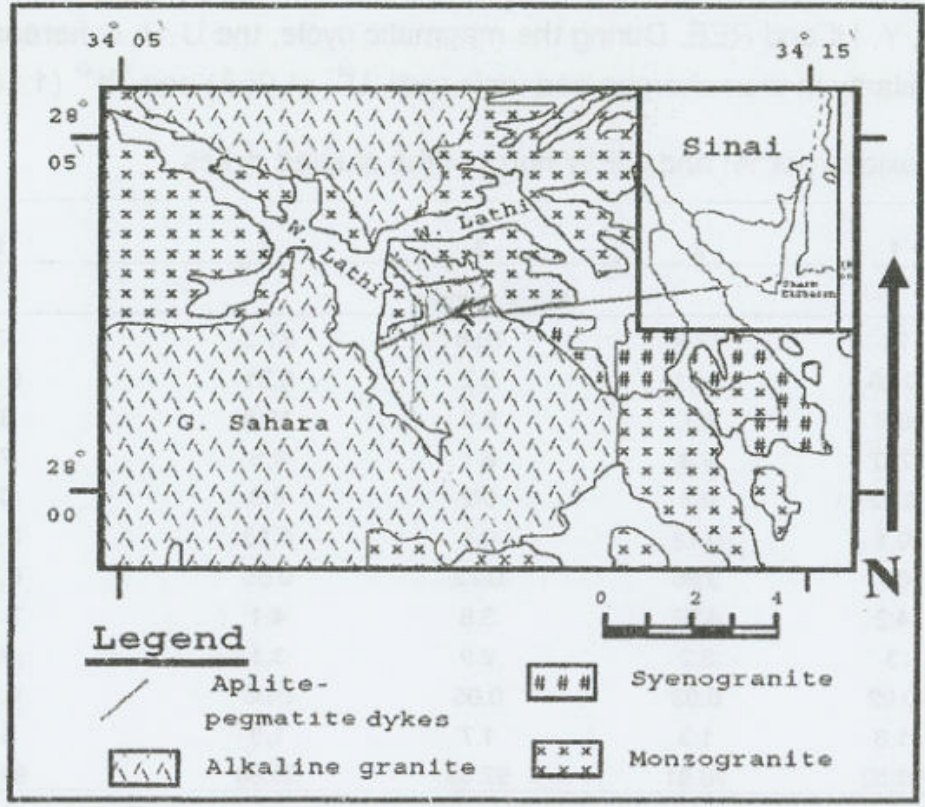

Fig. (1): Geologic map of aplite-pegmatite dykes, north Ras Mohamed, Sinai, Egypt.(Modified after Moselhi, 2006)

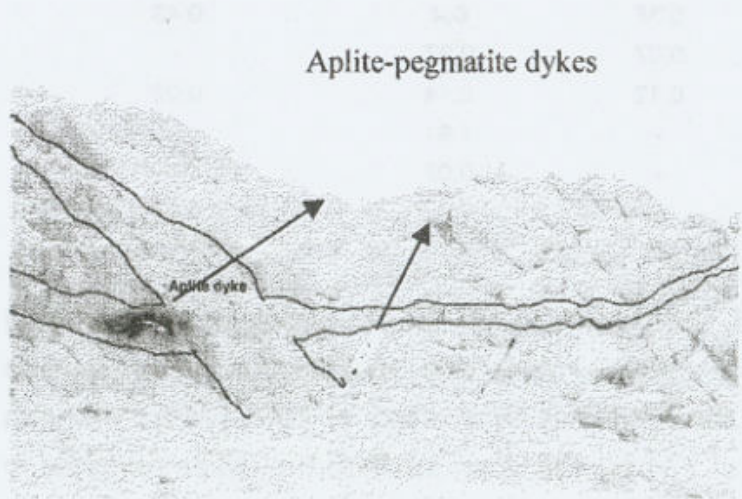

Fig. (2): Aplite-pegmatite dykes hosted by alkaline granites

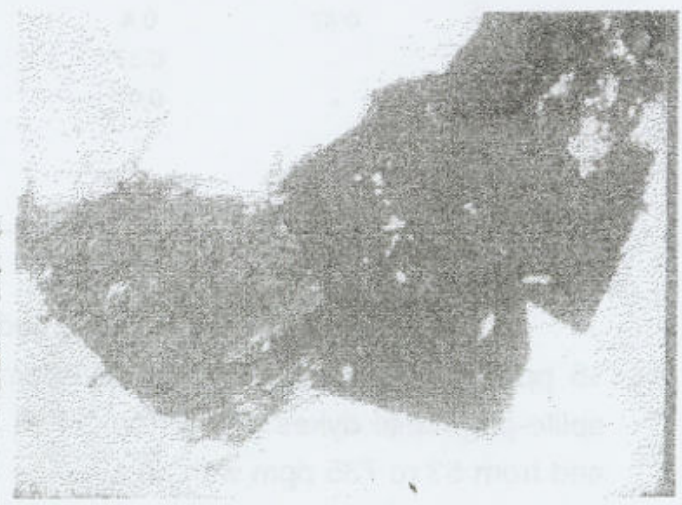

Fig. (3): Microphotograph shows sodic amphibole (S) in aplite dykes (PPL., $\mathrm{x} 25)$.

Shand's index diagram is originally used to distinguish between metaluminous, peraluminous and alkaline rock suites. The data of the studied samples plot within the peralkaline field, accept one sample filled in metaluminous field (Fig. $5)$.

Batchelor and Bowden (1985) used the R1and R2 multi-cationic parameters of De La Roche et al. (1980) to discriminate between the different tectonic settings of granitoid rocks, (Fig. 6). The studied aplite-pegmatite samples fall near the Post-Orogenic field. 
Trace and rare earth elements contents are listed in Tables (2 and 3) respectively. The data show that the aplite-pegmatite dykes are enriched in some trace elements such as $\mathrm{U}, \mathrm{Th}, \mathrm{Nb}, \mathrm{Ta}, \mathrm{Zr}, \mathrm{Y}, \mathrm{Hf}$ and REE. During the magmatic cycle, the $\mathrm{U}$-Th coherence attributed to the marked similarity in their charges and ionic radii, $U^{4+}(1.05 \AA)$ and $T h^{4+}(1.10 \AA)$.

Table 1. Major oxides (wt \%) and CIPW norm of the studied dykes.

\begin{tabular}{|c|c|c|c|c|c|}
\hline $\begin{array}{l}\text { Sample } \\
\text { No. }\end{array}$ & 1 & 2 & 3 & 4 & 5 \\
\hline \multicolumn{6}{|c|}{ Major oxides } \\
\hline $\mathrm{SiO}_{2}$ & 71 & 72.6 & 70.8 & 71.5 & 72 \\
\hline $\mathrm{TiO}_{2}$ & 0.28 & 0.21 & 0.2 & 0.21 & 0.23 \\
\hline $\mathrm{Al}_{2} \mathrm{O}_{3}$ & 9.6 & 8.7 & 9.3 & 10.8 & 8.7 \\
\hline $\mathrm{Fe}_{2} \mathrm{O}_{3}$ & 7.6 & 6.8 & 8.1 & 6.5 & 7.9 \\
\hline $\mathrm{MnO}$ & 0.22 & 0.3 & 0.2 & 0.3 & 0.2 \\
\hline $\mathrm{MgO}$ & 0.1 & 0.12 & 0.1 & 0.16 & 0.51 \\
\hline $\mathrm{CaO}$ & 0.7 & 0.66 & 0.73 & 0.65 & 0.74 \\
\hline $\mathrm{Na}_{2} \mathrm{O}$ & 4.2 & 4.99 & 3.8 & 4.1 & 3.99 \\
\hline $\mathrm{K}_{2} \mathrm{O}$ & 3 & 3.2 & 2.9 & 3.1 & 3.1 \\
\hline $\mathrm{P}_{2} \mathrm{O}_{5}$ & 0.02 & 0.03 & 0.05 & 0.06 & 0.01 \\
\hline L.O.I & 1.8 & 1.3 & 1.7 & 1.3 & 1.6 \\
\hline Total & 98.52 & 98.91 & 97.88 & 98.68 & 98.98 \\
\hline \multicolumn{6}{|c|}{ CIPW norm } \\
\hline$Q z$ & 34.87 & 33.99 & 36.84 & 34.52 & 36.82 \\
\hline or & 17.73 & 18.91 & 17.14 & 18.32 & 18.32 \\
\hline$A b$ & 32.68 & 26.94 & 31.69 & 34.69 & 27.49 \\
\hline$A c$ & 2.52 & 13.46 & 0.4 & - & 5.52 \\
\hline Di & 0.54 & 0.64 & 0.54 & 0.72 & 2.74 \\
\hline Wo & 1.06 & 0.94 & 1.09 & - & 0.03 \\
\hline $\mathrm{Hm}$ & 6.73 & 0.89 & 7.91 & 6.24 & 5.99 \\
\hline$\|$ & 0.47 & 0.4 & 0.38 & 0.4 & 0.43 \\
\hline$M t$ & - & 0.37 & 0.07 & 0.37 & - \\
\hline$A p$ & - & 0.07 & 0,12 & 0.14 & 0.02 \\
\hline$A n$ & - & - & $\cdot$ & 1.91 & - \\
\hline Hy & - & - & - & 0.07 & - \\
\hline$T n$ & - & - & - & - & 0.01 \\
\hline
\end{tabular}

The estimated averages of $U$ and Th contents in the granitoid rocks are 4 ppm and $18 \mathrm{ppm}$ respectively (Rogers and Adams, 1969). The $U$ and Th contents in the studied aplite-pegmatite dykes range from 19 to $305 \mathrm{ppm}$ with an average of $103 \mathrm{ppm}$ for uranium and from 53 to $735 \mathrm{ppm}$ with an average of $274 \mathrm{ppm}$ for thorium. Also the dykes enriched in $\mathrm{Nb}(91.7-5121.9 \mathrm{ppm})$ with an average of $1485.3 \mathrm{ppm}$, Ta $(8.5-693.5 \mathrm{ppm})$ with an average $208.1 \mathrm{ppm}, \mathrm{Zr}(623-16950.4 \mathrm{ppm})$ with an average $3967 \mathrm{ppm}, \mathrm{Y}(81.9-1915.8$ $\mathrm{ppm})$ with an average $569.5 \mathrm{ppm}$ and $\sum \operatorname{REE}(143.36-2271.49 \mathrm{ppm})$ with an average $1143.2 \mathrm{ppm}$.

High field strength cations include the lanthanides $\mathrm{Sc}$ and $\mathrm{Y}$, and $\mathrm{Th}, \mathrm{U}, \mathrm{Pb}, \mathrm{Zr}, \mathrm{Hf}$, $\mathrm{Ti}, \mathrm{Nb}$ and $\mathrm{Ta}$. The element pairs $\mathrm{Th}$ and $\mathrm{U}$, and, $\mathrm{Nb}$ and $\mathrm{Ta}$, and, $\mathrm{La}$ and $\mathrm{Y}$, and, $\mathrm{Zr}$ and $\mathrm{Hf}$ are very similar in size and charge and show very similar geochemical behaviour as shown in figure 7A-D. The low field strength large ion lithophile cations include $\mathrm{Cs}$ and $\mathrm{Rb}, \mathrm{Ba}$ and $\mathrm{Rb}$ (Fig. 7E-F). The plot samples show a well developed positive correlation between those element pairs. 
Mahmoud M. A. Gabr ; Hydrothermal Zircon, Nb-Ta and REE mineralization.......

On the other hand, the geochemical behaviour of REE is intrinsically interesting but use of REE abundances in determining evolutionary histories of suites of rocks is even more interesting and important. The REE are used to illustrate the petrogenesis of a rock after being normalized to a common reference standard, which most commonly comprises the values for chondritic meteorites. The rare earth elements of the studied dykes are normalized to chondrite values cited in Nakamura (1974).

The chondrite-normalized REE patterns are shown in figure (8). It shows moderate to large negative Eu anomalies and a wide variation in $\sum R E E$ in addition to the tetrad effect. Highly fractionated magma is suggested for the studied dykes since the pattern has moderate to large negative Eu (Henderson 1984). It is conformable with the field relation since the aplite-pegmatite dykes are late stage magmatism.

The most of recent discussion about the tetrad effect focus on highly evolved igneous rocks (Bau, 1996, 1997; Pan 1997) which are often interpreted as transitional between the end - members of magmatic and high-temperature hydrothermal systems.

To determine the hypothetical tetrad effect-free REE pattern according to Irber (1999), the corner points of the single tetrads La-Nd (and Gd-Ho) serve as a respective reference. A virtual line is drawn in between these corner points, and the mean deviation of $\mathrm{Ce}$ and $\mathrm{Pr}$ (and $\mathrm{Tb}, \mathrm{Dy}$ ) from this line expresses the contribution of the respective tetrad (equations 1 and 2)

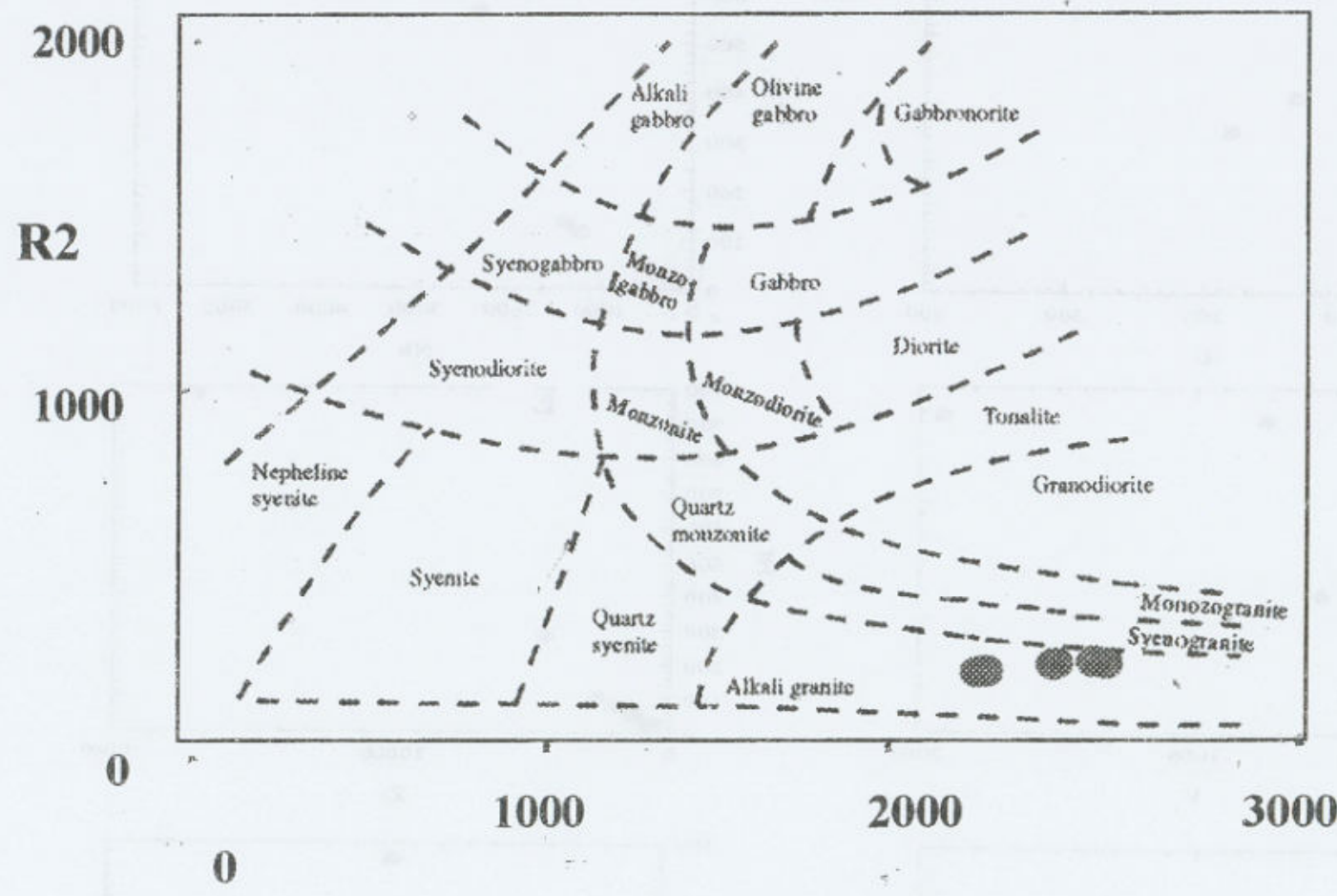

R1

Fig. (4): Chemical classification of the studied aplite-pegmatite dykes, using R1-R2 Millicationic proportions (after De La Roche et al., 1980) 

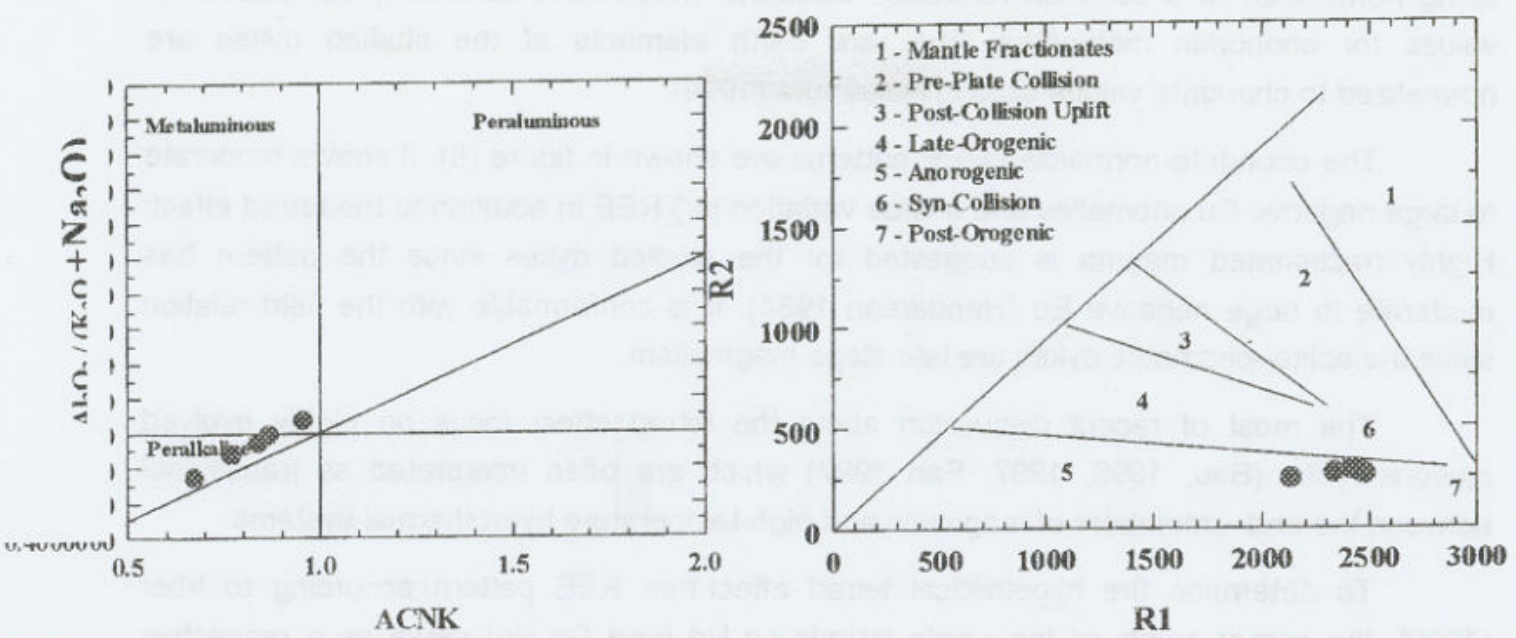

Fig. ( 5): Shand's index for the studied dykes Fig.( 5): Shand's index for the studied dykes

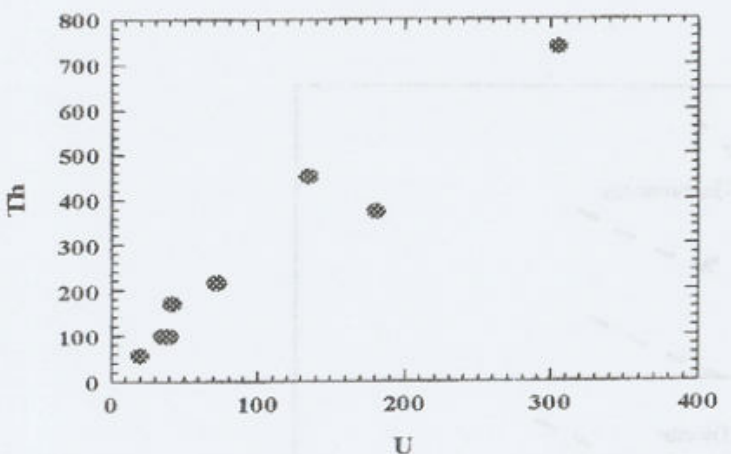

Fig.(6): Timing of emplacement of the studied dykes
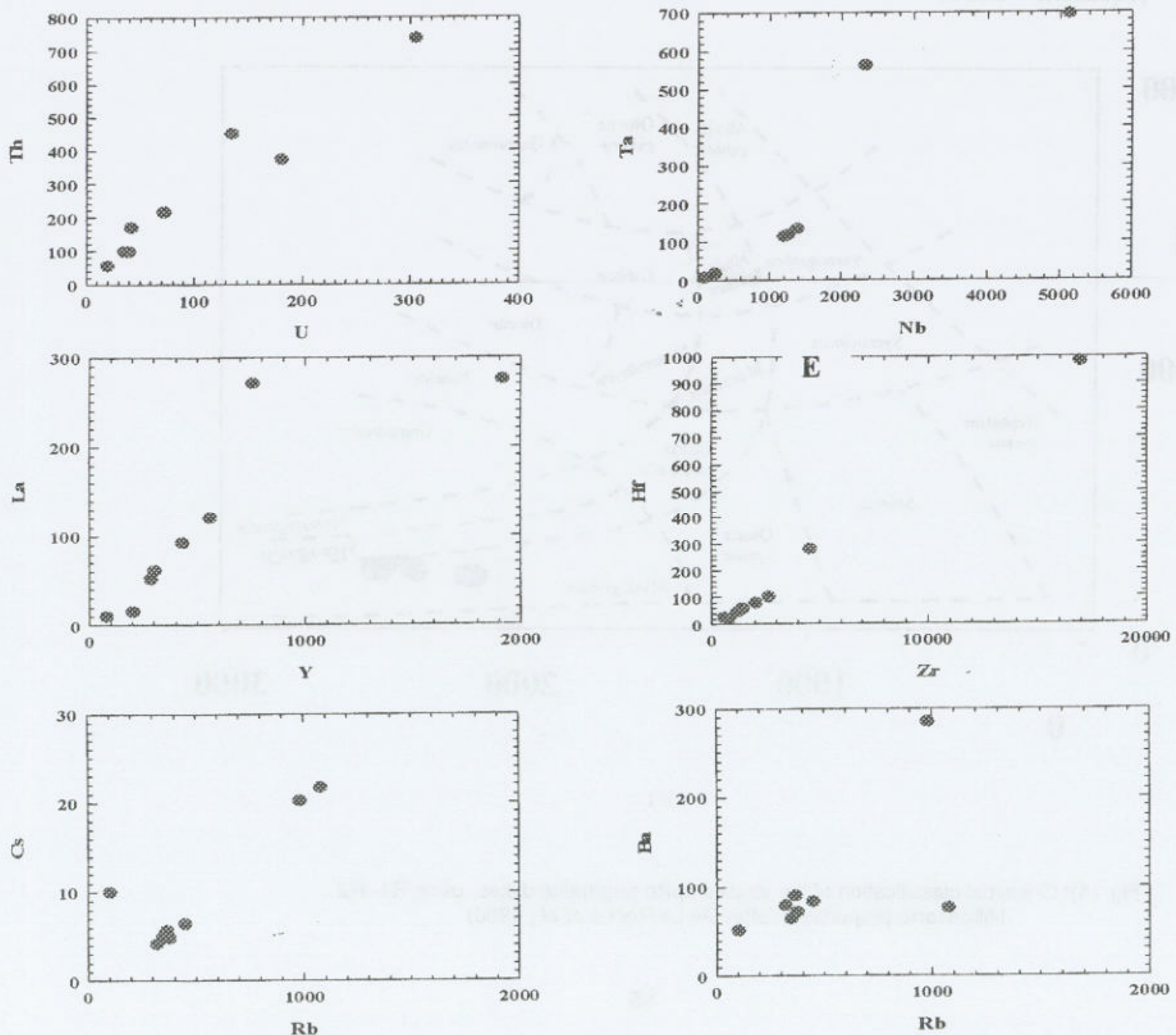

Fig. 7A-F. Variation diagrams between pairs of similar geochemical behaviour for some trace elements 


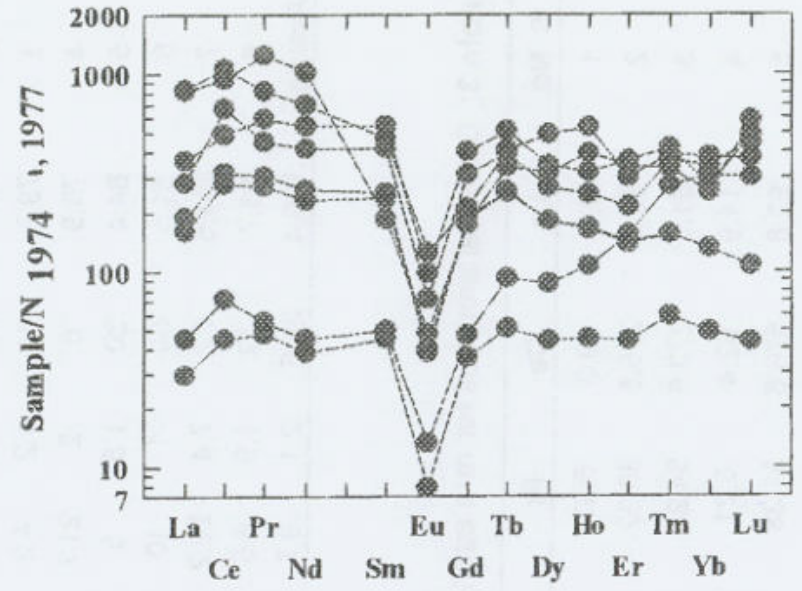

Fig. (8): Normalized REE distribution pattern for the studied dykes.

The geometric mean of both values for the frist $\left(t_{1}\right)$ and the third tetrad $\left(t_{3}\right)$ yields the overall value of the tetrad effect (equation $3: T E_{1.3}$ ).

$$
\begin{aligned}
& t_{1}=\left(\mathrm{Ce} / \mathrm{Ce}^{*} \times \mathrm{Pr} / \mathrm{Pr}^{*}\right)^{0.5} \\
& t_{3}=\left(\mathrm{Tb} / \mathrm{Tb}^{*} \times \mathrm{Dy} / \mathrm{Dy}^{*}\right)^{0.5}
\end{aligned}
$$

where

$$
\begin{aligned}
& \mathrm{Ce} / \mathrm{Ce}^{\star}=\mathrm{Ce}_{\mathrm{cn}} /\left(\mathrm{La}_{\mathrm{cn}}{ }^{2 / 3} \times \mathrm{Nd}_{\mathrm{cn}}{ }^{1 / 3}\right) \\
& \mathrm{Pr} / \mathrm{Pr}^{\star}=\mathrm{Pr}_{\mathrm{cn}} /\left(\mathrm{La}_{\mathrm{cn}}{ }^{1 / 3} \times \mathrm{Nd}_{\mathrm{cn}}{ }^{2 / 3}\right) \\
& \mathrm{Tb} / \mathrm{Tb}^{\star}=\mathrm{Tb}_{\mathrm{cn} /} /\left(\mathrm{Gd}_{\mathrm{cn}}{ }^{2 / 3} \times \mathrm{Ho}_{\mathrm{cn}}{ }^{2 / 3}\right) \\
& \mathrm{Dy}^{2 / \mathrm{Dy}^{*}}=\mathrm{Dy}_{\mathrm{cn}} /\left(\mathrm{Gd}_{\mathrm{cn}}{ }^{1 / 3} \times \mathrm{Ho}_{\mathrm{cn}}{ }^{2 / 3}\right)
\end{aligned}
$$

Degree of the tetrad effect $\left.=T E_{1.3}=t_{1} \times t_{3}\right)^{0.5}$

The calculated values of the tetrad effect $\left(T E_{1.3}\right)$ range from 11.0 for a REE pattern without tetrad effect and only samples with values of $\mathrm{TE}_{1.3}>1.1$ are considered to show the tetrad effect.

The data of tetrad effect values for the studied aplite-pegmatite dykes are shown in Table 4. The values of tetrad effect $\left(T E_{1.3}\right)$ for all samples exceed 1.1 where the values range from 1.14 to 1.31 which means that all samples have well visible tetrad effect. 


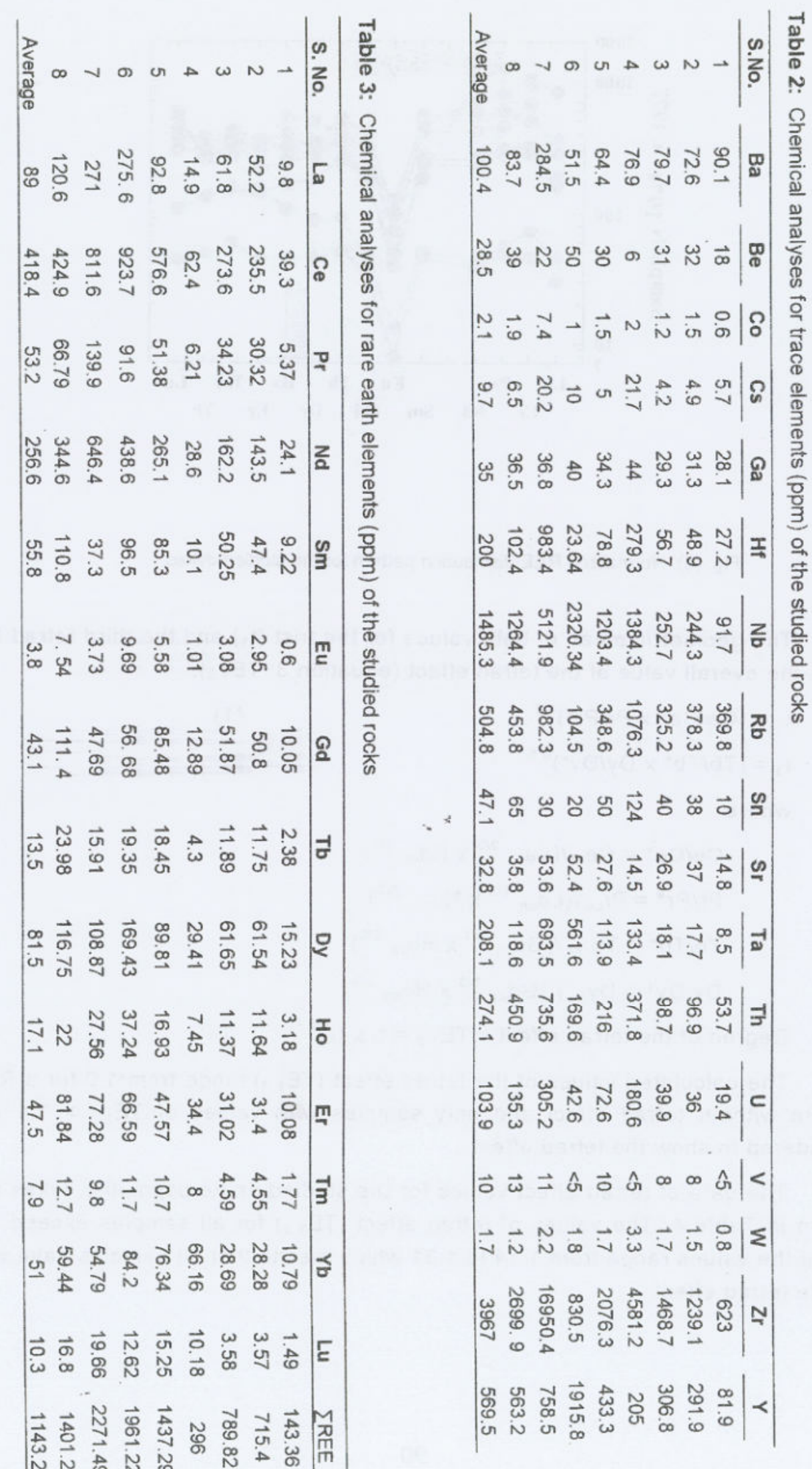


Table 4. Theoretical values of tetrad effect for the studied rocks

\begin{tabular}{ccccccccc}
\hline Sample No. & $\mathrm{Eu} / \mathrm{Eu}^{*}$ & ${\mathrm{Ce} / \mathrm{Ce}^{*}}^{*}$ & ${\mathrm{Pr} / \mathrm{Pr}^{*}}^{*}$ & ${\mathrm{~Tb} / \mathrm{Tb}^{*}}^{*}$ & $\mathrm{Dy} / \mathrm{Dy} \mathrm{y}^{*}$ & $\mathrm{t}_{1}$ & $\mathrm{t}_{3}$ & $\mathrm{TE}_{1,3}$ \\
\hline 1 & 0.19 & 1.36 & 1.32 & 1.2 & 1.01 & 1.34 & 1.1 & 1.21 \\
2 & 0.18 & 1.47 & 1.3 & 1.31 & 1 & 1.38 & 1.14 & 1.26 \\
3 & 0.18 & 1.45 & 1.27 & 1.32 & 1 & 1.37 & 1.16 & 1.26 \\
4 & 0.27 & 1.54 & 1.18 & 1.39 & 1 & 1.35 & 1.19 & 1.26 \\
5 & 0.2 & 2 & 1.2 & 1.28 & 0.96 & 1.55 & 1.11 & 1.31 \\
6 & 0.4 & 1.31 & 1.07 & 1.36 & 1.2 & 1.18 & 1.29 & 1.23 \\
7 & 0.27 & 1.02 & 1.27 & 1.4 & 1.02 & 1.14 & 1.19 & 1.16 \\
8 & 0.2 & 1.13 & 1.2 & 1.3 & 0.96 & 1.17 & 1.11 & 1.14 \\
\hline
\end{tabular}

\section{Mineralogy}

\section{Methodology}

Five samples were selected for mineralogical studies. These samples were crushed and sieved to the fraction between $(-500 \mathrm{~mm}$ and $0.063 \mathrm{~mm}$ grain size) The obtained fractions were separated by heavy liquids technique and isodynamic magnetic separator at $0.5 \mathrm{~A}^{\circ}, 0.7 \mathrm{~A}^{\circ}, 1.0 \mathrm{~A}^{\circ}, 1.2 \mathrm{~A}^{\circ}$ and $1.5 \mathrm{~A}^{\circ}$. The obtained heavy fractions were hand picked with binocular microscope and then analyzed by SEM attached with EDAX unit. The analyses were carried out at the Central Laboratories of Nuclear Materials Authority, Cairo, Egypt.

SEM technique analyses reveal the presence of some minerals such as hydrothermal zircon which recorded for the first time in Sinai as far as the author is aware, columbite minerals group and Tornebohmite-(Ce) minerals.

\section{Hydrothermal zircon}

The term "hydrothermal zircon" is an imprecise term that may in a general way be used to refer to zircon crystallized from or altered by an aqueous fluid. In detail, however, there are three distinct mechanisms forming hydrothermal zircon although the zircon they produce may share trace-element characteristics:

(i) Dissolution-reprecipitation, documented for high-pressure/lowtemperature meta-igneous rocks (Tomaschek et al., 2003).

(ii) lon-exchange between low-temperature $\left(120\right.$ to $\left.200^{\circ} \mathrm{C}\right)$ aqueous fluid and amorphized (metamict) zircon and structural recovery as described experimentally (Geisler et al., 2003a) and for zircon from the Eastern Desert, Egypt (Geisler et al., 2003b).

(iii) Direct crystallization by a (locally?) zircon-saturated aqueous fluid, as described by Hoskin (2005).

The studied hydrothermal zircon is formed by direct crystallization from zircon-saturated aqueous fluid. It often has a "spongy," pitted appearance. Backscatter-electron imaging shows that the hydrothermal zircon (both aggregates and single crystals) to be unzoned with a slightly brighter response (i.e., black in gray-scale imaging). The hydrothermal zircon occurs usually as aggregates and has heterogeneous composition. Three grains are studied as 
profile from the bright colour to dark colour to reveal the difference in composition in one grain. The EDAX results are shown in figs. 9-11. The EDAX results show general enrichment of zircon with trace elements such as $\mathrm{U}, \mathrm{Th}$ and $\mathrm{Hf}$, and rare earth elements (REE). It is noted that the $\mathrm{Zr}$ decreases with increasing of $\mathrm{Th}$ and $U$ in the same grain (Figs.9-11). The hydrothermal zircon is recorded for the first time in Sinai, Egypt as far as the author is aware.

\section{Columbite group}

The columbite group of minerals has the general formula AB206, in which, most typically, $A$ represents $\mathrm{Fe}^{+2}, \mathrm{Mn}$, and $\mathrm{Mg}$, and $\mathrm{B}$ represents $\mathrm{Nb}$ and $\mathrm{Ta}$. These minerals are associated with rare-earth pegmatites and are also known from placer deposits. Most of the compounds probably formed initially with $\mathrm{U}^{4+}$, most probably as a coupled substitution $\mathrm{Ca}^{2+}+\mathrm{U}^{4+}$ for a trivalent ion. Those minerals which contain radioactive elements are usually metamict and require heating to develop crystallinity (Smith, 1984).

Samarskite $(\mathrm{Y}, \mathrm{Ce}, \mathrm{U}, \mathrm{Ca}, \mathrm{Fe})(\mathrm{Nb}, \mathrm{Ta}, \mathrm{Ti})_{2} \mathrm{O}_{6}$

Samarskite is common enough and locally abundant enough that it has potential to be a valuable resource for its rare earth metals. It is usually associated with quartz, feldspars, tantalate and rare earth minerals. It is dark black to dark brown colour and has subconchoidal fracture. The EDAX analyses (Fig. 12)

\section{Ferrocolumbite mineral}

It has formula $\left(\mathrm{Fe}^{2+} \mathrm{Nb}_{2} \mathrm{O}_{6}\right)$. The EDAX analyses reveal the presence of ferrocolumbite mineral (Fig. 13). Ferrocolumbite minerals are characterized by dark pitchy to dark brown colour with conchoidal fracture.

\section{Tornebohmite-(Ce) minerals}

It has formula $(\mathrm{Ce}, \mathrm{La})_{2} \mathrm{Al}\left(\mathrm{SiO}_{4}\right)_{2}(\mathrm{OH})$. It is important resource for REE (Fig. 14).

\section{Conclusion}

The detailed field studies reveal the presence of NE-SW, E-W, N-S and NW-SE trending alkaline pegmatite-aplite dyke system hosted by alkaline granite at north Ras Mohammed area, south Sinai, Egypt. It consists of brown-red dykes up to several kilometers long and 0.4 to $1 \mathrm{~m}$ wide. The dykes are fine to medium-grained rocks with granular texture and are mainly composed of $\mathrm{K}$-feldspar as microperthite, quartz, riebeckite and plagioclase. The dykes have anomalous radioactivity up to $305 \mathrm{ppm} U$ due to the presence of the uranium mineral samarskite and hydrothermal zircon. The dykes are characterized by the presence of hydrothermal zircon (enriched with $U$, Th and trace elements) in addition to $U$ (19 to $305 \mathrm{ppm}$ ), Th (53 to $735 \mathrm{ppm}$ ), Nb (91.7 to $5121.9 \mathrm{ppm}), \mathrm{Ta}$ (8.5 to $693.5 \mathrm{ppm}), \mathrm{Y}$ (81.9 to $1915.8 \mathrm{ppm}$ ), $\mathrm{Zr}$ (623 to $16950.4 \mathrm{ppm}$ ), La (9.8 to $275.6 \mathrm{ppm}$ ), Ce (39.3 to 923.7 $\mathrm{ppm})$ and EREE (143.36 to $2271.49 \mathrm{ppm}$ ). The distribution of the trace elements in the aplite-pegmatite dykes can be understood on basis of the behaviour of these elements during the course of magma evolution. When the earth's mantle is melted, trace elements display a preference either for the melt phase or the solid mineral phase. 
Mahmoud M. A. Gabr : Hydrothermal Zircon, Nb-Ta and REE mineralization......
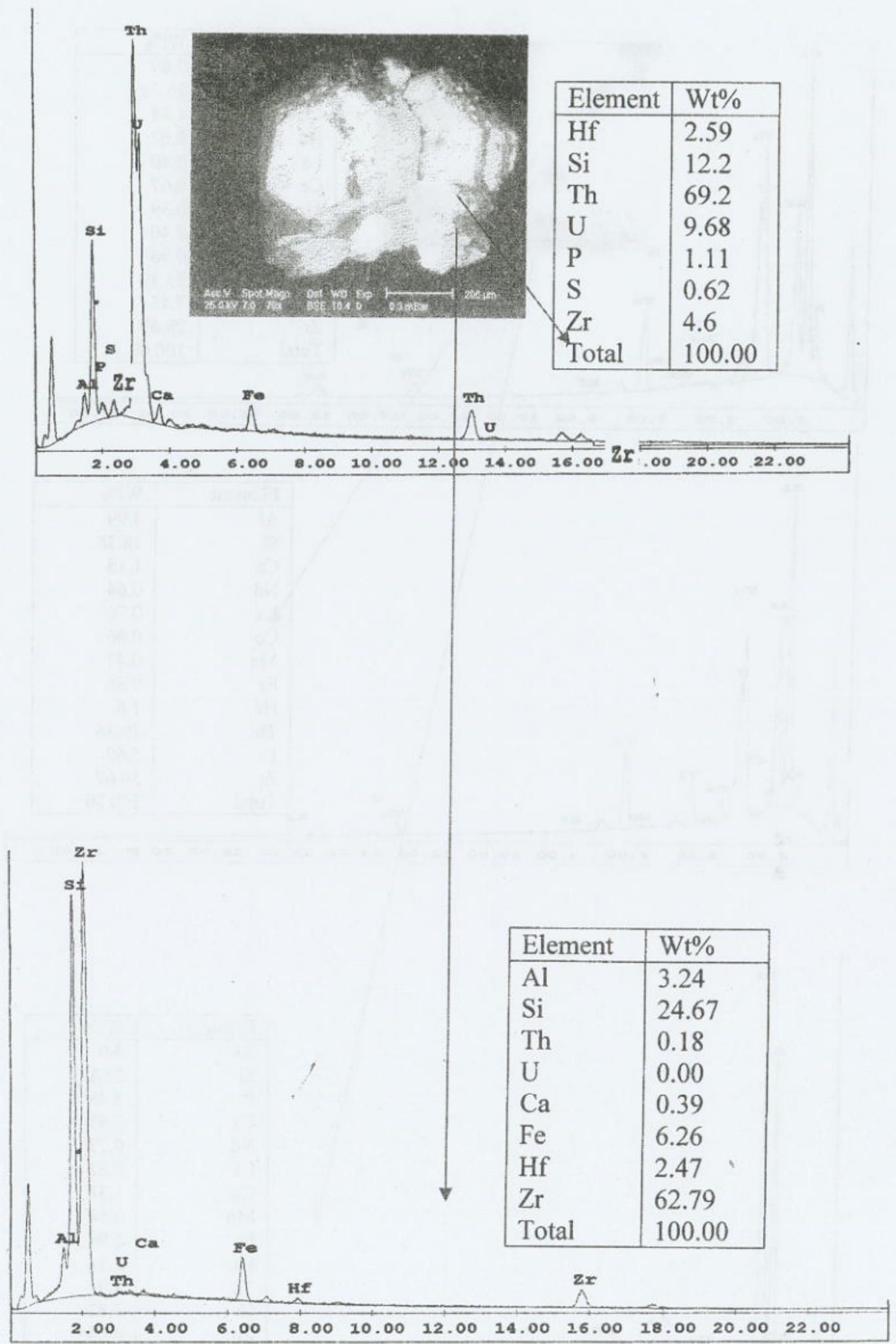

Fig.(9): SEM-EDAX semiquantitative compositional data for hydrothermal zircon 
Delta J. Sci., 31: 84- 99 (2007)
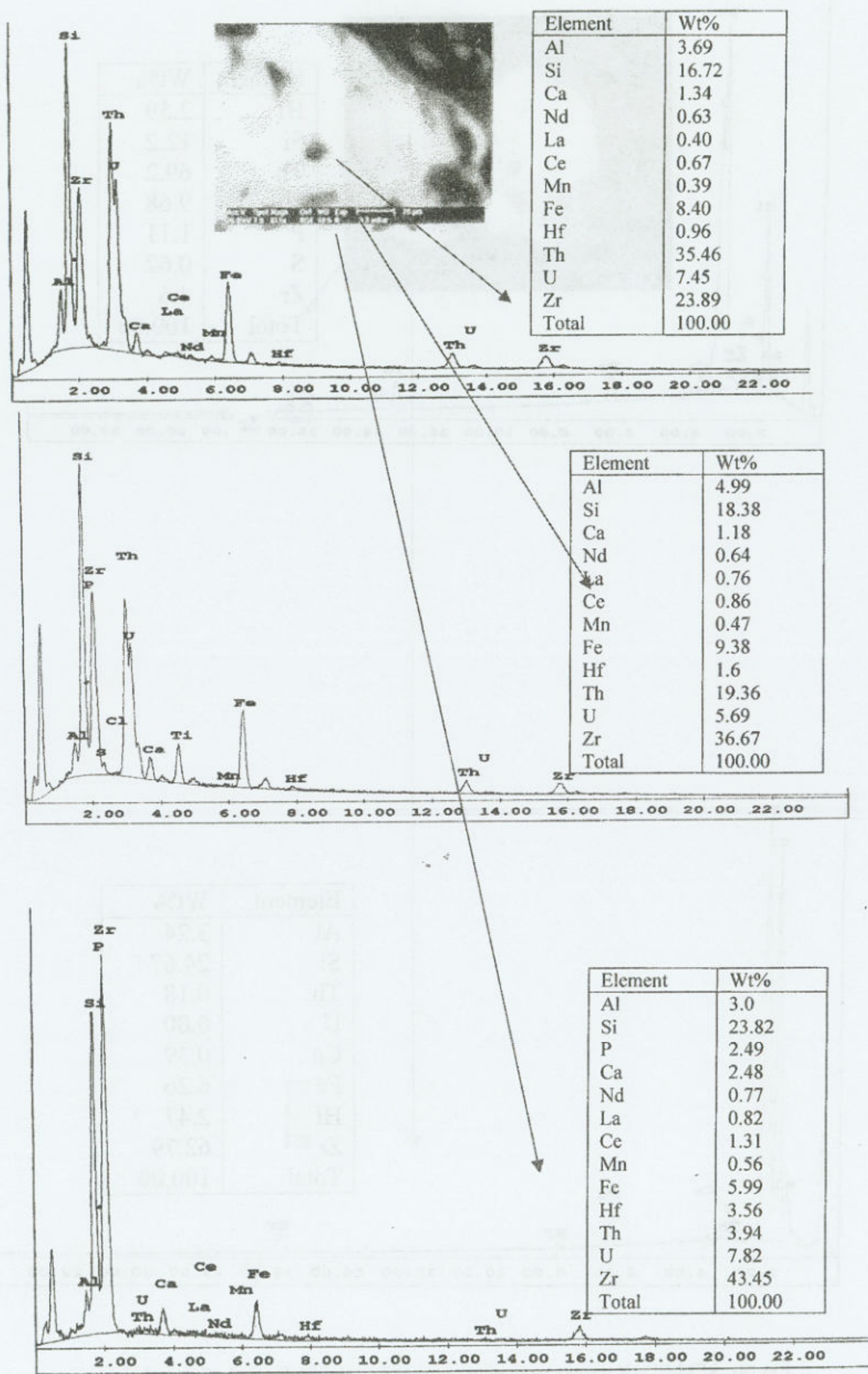

Fig. (10): SEM-EDAX semiquantitative compositional data for hydrothermal zircon mineral 
Mahmoud M. A. Gabr ; Hydrothermal Zircon, Nb-Ta and REE mineralization......

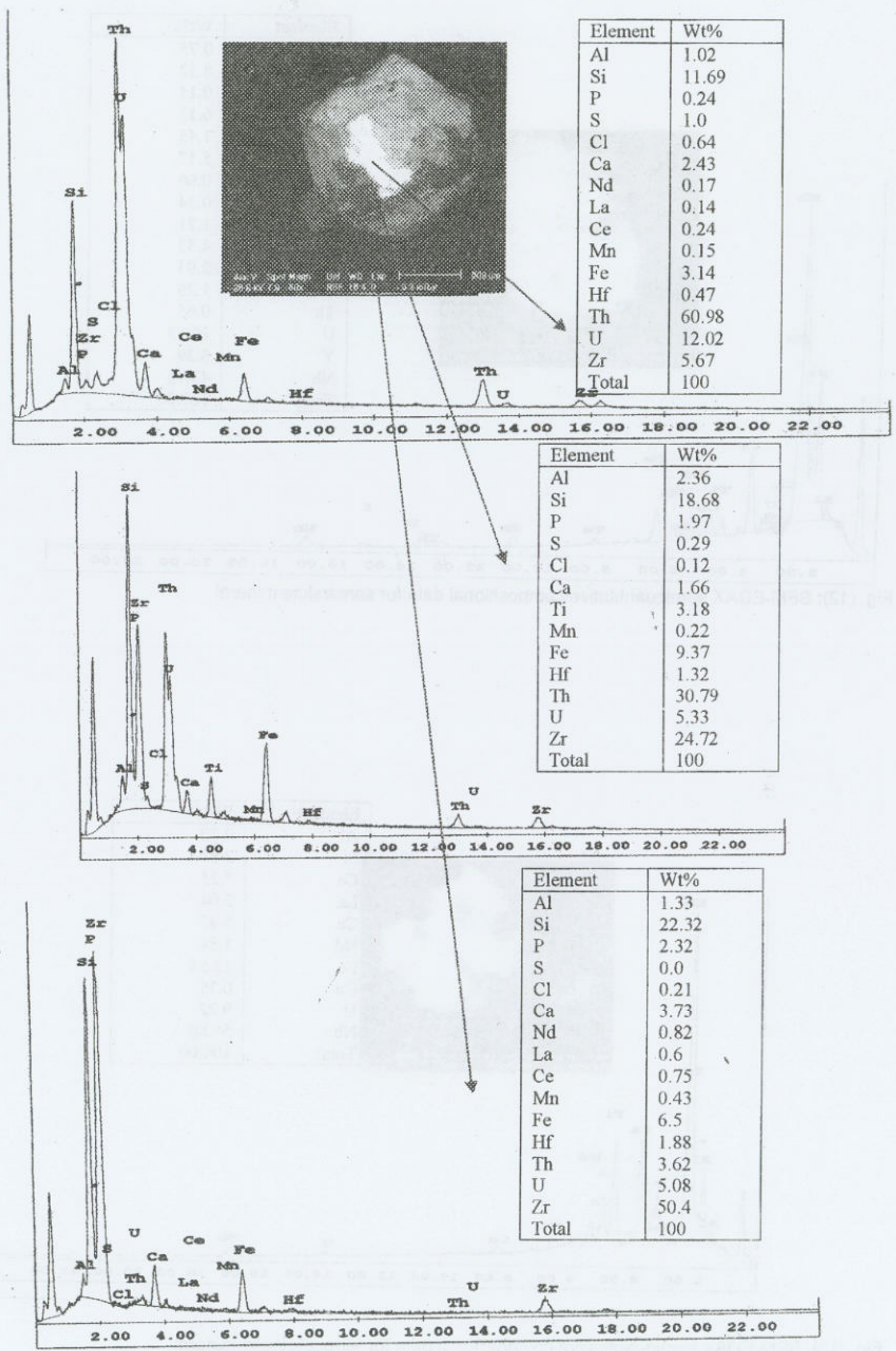

Fig. (11): SEM-EDAX semiquantitative compositional data for hydrothermal zircon 


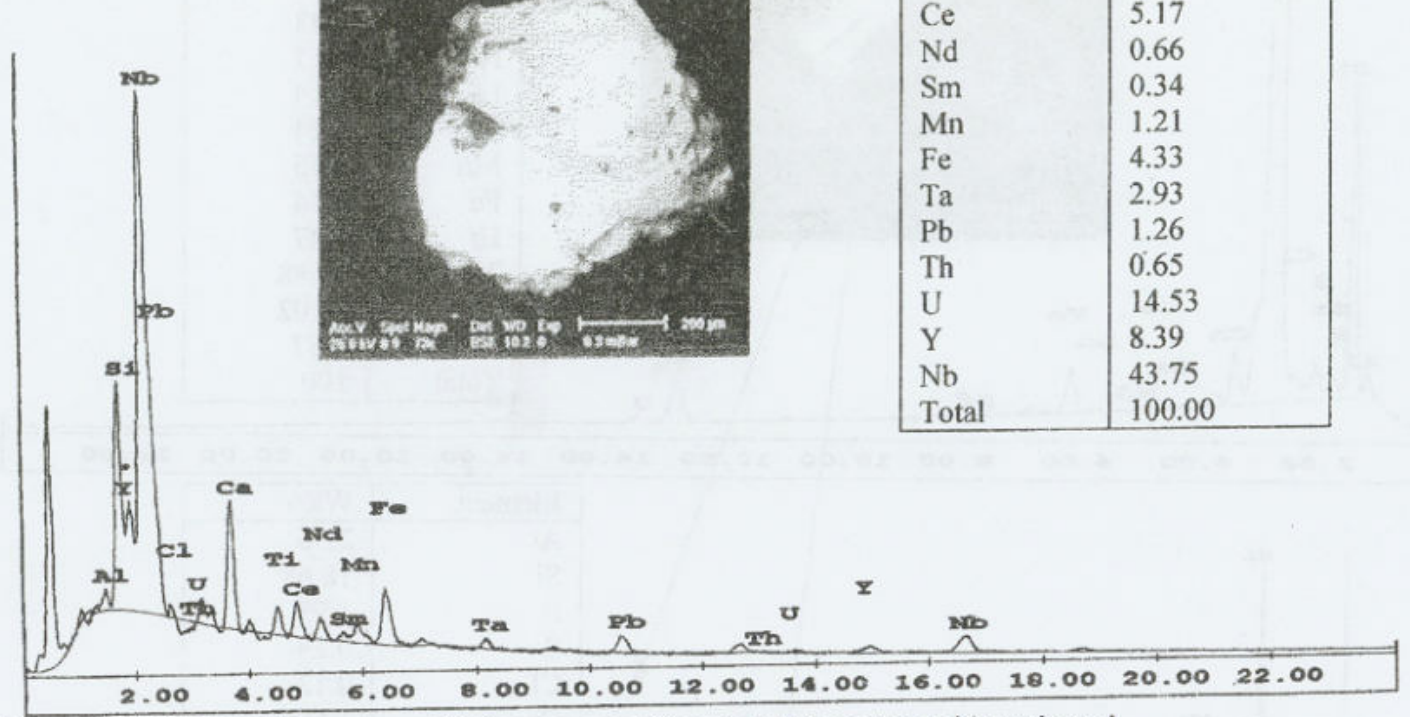

\begin{tabular}{|l|l|}
\hline Element & Wt\% \\
\hline $\mathrm{Al}$ & 0.75 \\
$\mathrm{Si}$ & 8.32 \\
$\mathrm{Cl}$ & 0.14 \\
$\mathrm{Ca}$ & 6.13 \\
$\mathrm{Ti}$ & 1.45 \\
$\mathrm{Ce}$ & 5.17 \\
$\mathrm{Nd}$ & 0.66 \\
$\mathrm{Sm}$ & 0.34 \\
$\mathrm{Mn}$ & 1.21 \\
$\mathrm{Fe}$ & 4.33 \\
$\mathrm{Ta}$ & 2.93 \\
$\mathrm{~Pb}$ & 1.26 \\
$\mathrm{Th}$ & 0.65 \\
$\mathrm{U}$ & 14.53 \\
$\mathrm{Y}$ & 8.39 \\
$\mathrm{Nb}$ & 43.75 \\
$\mathrm{Total}$ & 100.00 \\
\hline
\end{tabular}

Fig. (12): SEM-EDAX semiquantitative compositional data for samarskite mineral

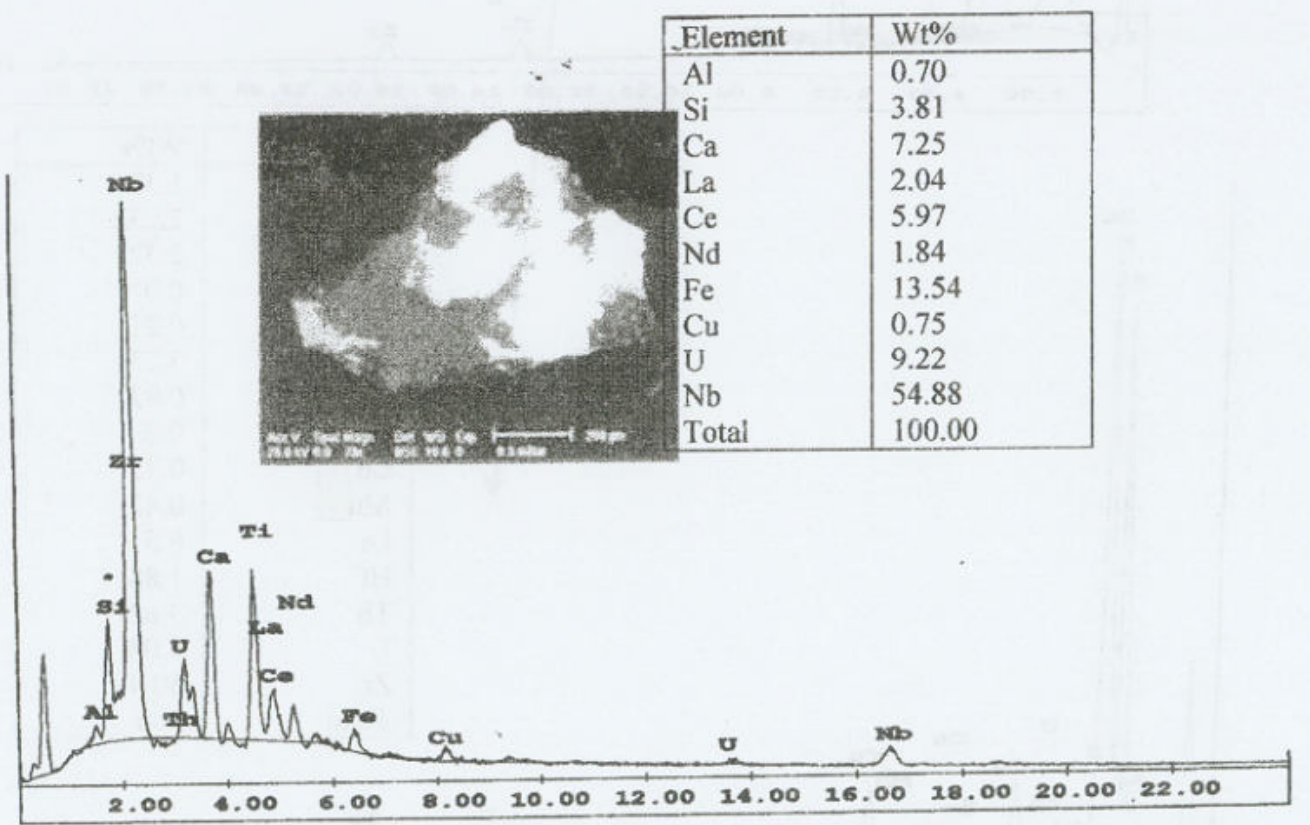

Fig. (13): SEM-EDAX semiquantitative compositional data for ferrocolumbite mineral 
Mahmoud M. A. Gabr ; Hydrothermal Zircon, Nb-Ta and REE mineralization......

Trace elements whose preference is the mineral phase are described as compatible, whereas elements whose preference is the melt are described as incompatible-i.e. they are incompatible in the mineral structure and will leave at the first available opportunity. Incompatible elements have also been called hyromagmatophile, a term first introduced by Treuil and Varet (1973).

The scan electron microscope studies reveal the presence of hydrothermal zircon, columbite mineral group and Tornebohmite-(Ce) minerals.

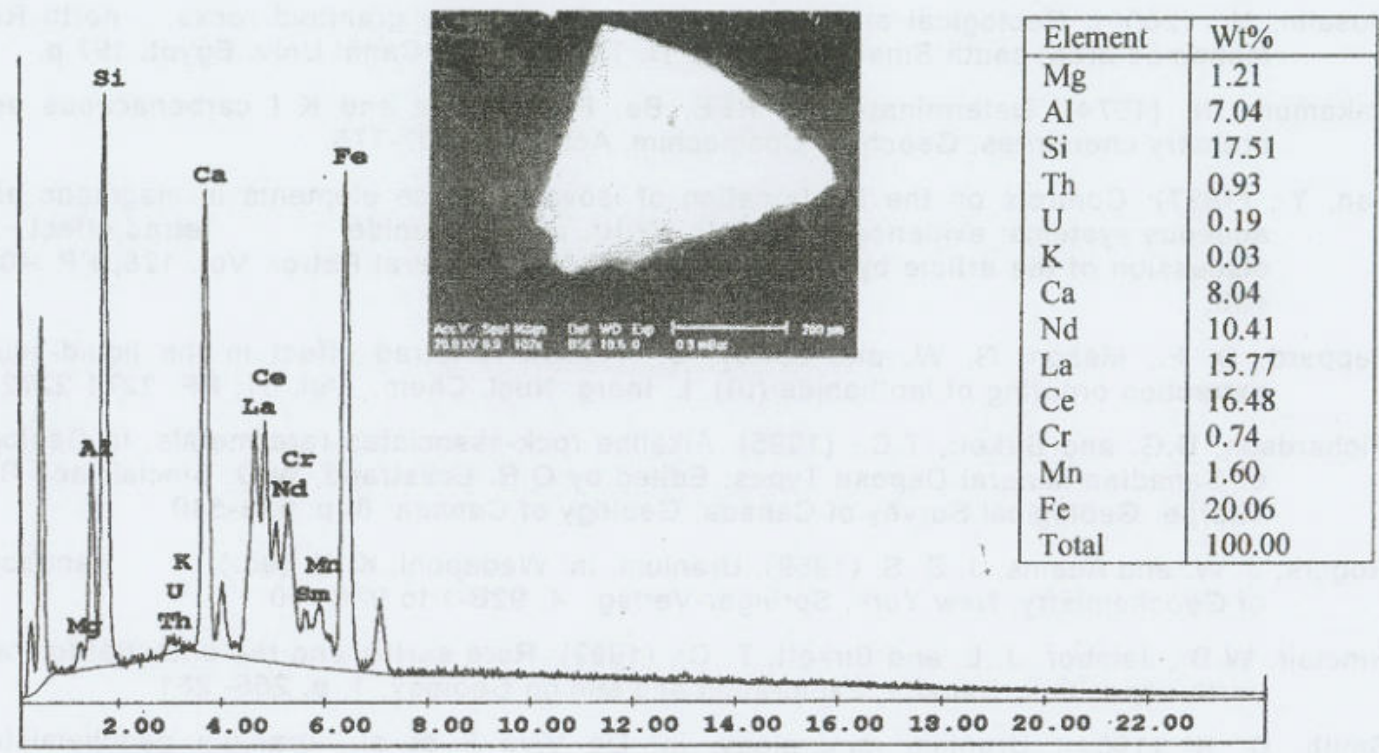

Fig. (14): SEM-EDAX semiquantitative compositional data for Tornebohmite-(Ce)

\section{References}

Batchelor, R. A. and Bowden, P. (1985): Petrogenetic interpretation of granitoid rock series using multicationic parameters. Chem. Geol., 48, 43-55. Amsterdam.

Bau, M. (1996): Controls on the fractionation of isovalent trace elements in magmatic and aqueous systems: evidence from $\mathrm{Y} / \mathrm{Ho}, \mathrm{Zr} / \mathrm{Hf}$, and lanthanide tetrad effect. Contrib. mineral. Petrol., Vol. 123, P'P.323-333.

Clarke, D. B. (1992): Granitoid rocks, Topics In The Earth Science 7. Chapman \& Hall. London, $283 \mathrm{pp}$.

Currie, K. L., (1976): The Alkaline Rocks of Canada. Geological Survey of Canada, Bulletin $239,228 p$.

De La Roche, H., Letrrrier, J., Granclavde, P. and Marchal, M. (1980): A classification of plutonic and canic rocks using R1-R2 diagram and major elements analyses. Its relationships with current nomenclature. Chem. Geol., 29, 183-210.

Geisler T., Pidgeon R. T., Kurtz R., van Bronswijk W. and Schleicher H (2003a): Experimental hydrothermal alteration of partially metamict zircon. Am. Mineral. 88, 1496-1513.

Geisler T., Rashwan A. A., Rahn M. K. W., Poller U., Zwingmann H., Pidgeo R. T., Schleicher $H$. and Tomaschek $F(2003 \mathrm{~b})$ : Low temperature hydrothermal alteration of natural metamict zircons from the Eastern Desert, Egypt. Mineral. Mag. 67, pp. 485-508.

Henderson, P., (1984): Rare earth element geochemistry, developments in geochemistry 2 , Elsevier, Amsterdam, $510 \mathrm{pp}$.

Hoskin, P. W. O (1998): Trace-element composition of hydrothermal zircon and the alteration of Hadean zircon from the Jack Hills, Australia. Geochimica et Cosmochimica Acta, Vol. 69 , No. 3 , pp. 637-648. 
Irber, W. (1999): The lanthanide tetrad effect and its correlation with K/Rb, Eu/Eu*, Sr/Eu, $\mathrm{Y} / \mathrm{Ho}$, and $\mathrm{Zr} / \mathrm{Hf}$ of evolving peraluminous granite suite. GeochimCosmochim,. Acta Vol. 63. pp. 110-124.

Jackson, N. J., Drysdall, A. R. and Stoeser, D. B., (1985): Alkaii granite-related Nb-Zr-REE-UTh mineralization in the Arabian Shield In. High Heat Production (HHP) Cranites, Hydrothermal Circulation and Ore Genesis, The Institution of Mining and Metallurgy, London, PP. 479-487.

Kinnaird, J. A., Batchelor, R. A., Whitley, J. E. and Mackenzie, A. P., (1985): Geochemistry, mineralization and hydrothermal alteration of the Nigerian high heat producing granites. In, High Heat Production (HHP) Cranites, Hydrothermal Circulation and Ore Genesis, The Institution of Mining and Metallurgy, London, PP. 169-195

Mosalhi, M., (2006): Geological and radioactive studies on the granitoid rocks, north Ras Mohamed area, south Sinai, Egypt. Ph. D. Thesis, Suez Canal Univ. Egypt. 197 p.

Nakamura, N. (1974): Determination of REE, Ba, Fe, Mg, $\mathrm{Na}$ and $\mathrm{K} I$ carbonaceous and ordinary chondrites. Geochim. Cosmochim. Acta, 38, 757-775.

Pan, Y., (1997): Controls on the fractionation of isovalent trace elements in magmatic and aqueous systems: evidence from $\mathrm{Y} / \mathrm{Ho}, \mathrm{Zr} / \mathrm{Hf}$, and lanthanide tetrad effect - A discussion of the article by M. Bau (1996). Contrib. Mineral Petrol. Vol. 128, PP. 405408.

Peppard, D. F., Mason, G. W. and Lewey, S., (1969): A tetrad effect in the liquid-liquid extraction ordering of lanthanide (III). L. Inorg. Nucl. Chem., Vol. 31, PP. 2271-2272.

Richardson, D.G. and Birkett, T.C., (1995): Alkaline rock-associated rare metals. In Geology of Canadian Mineral Deposit Types. Edited by O.R. Eckstrand, W.D. Sinclair and R.I. Thorpe. Geological Survey of Canada, Geology of Canada, 8, p. 523-540.

Rogers, J. W. and Adams, J. S. S. (1969): Uranium. In: Wedepohl, K. H. (ed.), Handbook of Geochemistry, New York, Springer-Verlag, 4, 92B-1 to 92C -10.

Sinclair, W.D., Jambor, J. L. and Birkett, T. C., (1992): Rare earths and the potential for rare earth deposits in Canada. Exploration and Mining Geology, 1, p. 265- 281

Smith, D. K. (1984): Uranium mineralogy, in: De Vivo $F$ et al., uranium geochemistry, mineralogy, geology exploration and resources, I M M, London, pp. 43-88

Sorensen, H., (1992): Agpaitic nepheline syenites: A potential source of rare elements. Applied Geochemistry, 7, p. 417-427.

Tomaschek F., Kennedy A. K., Villa I. M., Lagos: M. and Ballhaus C. (2003): Zircons from Syros, Cyclades, Greece--recrystallization and mobilization of zircon during highpressure metamorphism. J. Petrol. 44, 1977-2002

Treuil, M. and Varet, J., (1973): Criteres volcanologiques, petrologiques et geochimique de la genese et de la differenciation des magmas basaltique: example de l'Afar. Bull. Geol. Soc. France, 7 th ser., 15, 401-644.

$$
\begin{aligned}
& \text { تمعدنات الزيركون الحرمائى و العناصر الارضية النادرة فى سدود }
\end{aligned}
$$

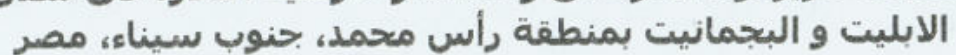

$$
\begin{aligned}
& \text { محمود محمد محمد على جبر لمالن } \\
& \text { هينة المواد النووية، مصر - ص.ب . به }
\end{aligned}
$$

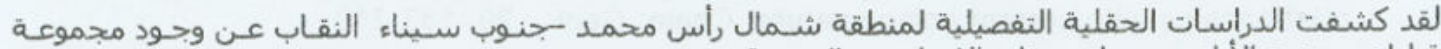

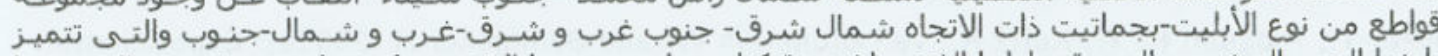

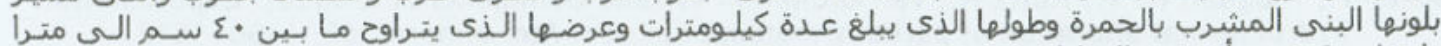

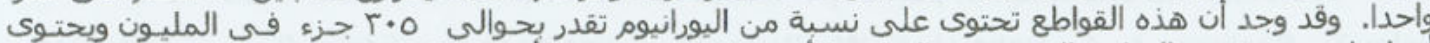

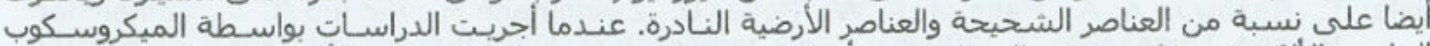

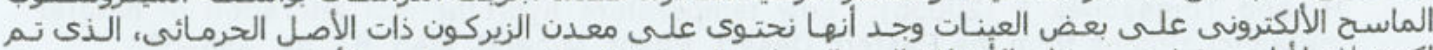

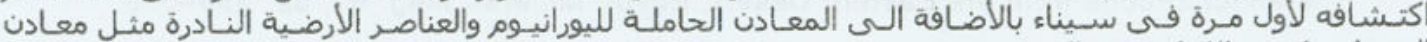
السمارسكيت والكولمبيت والتورة مالتورنبوهميت. بالاضيت. 